Int. J. Plant Sci. 164(3):405-413. 2003.

(C) 2003 by The University of Chicago. All rights reserved.

$1058-5893 / 2003 / 16403-0008 \$ 15.00$

\title{
VESTURED PITS: DO THEY PROMOTE SAFER WATER TRANSPORT?
}

\author{
Steven Jansen, ${ }^{1, *} \neq$ Pieter Baas, + Peter Gasson, $\neq$ and Erik Smets* \\ *Laboratory of Plant Systematics, Katholieke Universiteit Leuven, Institute of Botany and Microbiology, Kasteelpark Arenberg 31, B-3001 \\ Leuven, Belgium; +Nationaal Herbarium Nederland, Universiteit Leiden Branch, P.O. Box 9514, 2300 RA Leiden, The Netherlands; \\ and ¥Jodrell Laboratory, Royal Botanic Gardens, Kew, Richmond, Surrey TW9 3DS, United Kingdom
}

\begin{abstract}
The distribution of vestured pits in angiosperms is briefly reviewed. In some major clades, the character is of constant occurrence and thus very conservative; in others, it is more variable and apparently subject to both parallel origins and reversible losses. There is a striking correlation between the type of vessel perforation plate and vestured pits. Virtually all taxa with vestured pits have simple perforation plates. This correlation, together with contrasting ecological trends for scalariform perforation plates and vestured pits, has inspired functional hypotheses that vestured pits contribute to hydraulic safety. Whereas scalariform perforations may be instrumental in reducing the effects of freezing-induced embolisms in temperate to boreal and alpine regions, vestured pits seem to be a good candidate to facilitate embolism reversal in xeric and warmer regions with high transpiration rates. The presence of highly lignified structures within the pit chamber may influence hydraulic resistance, decrease vulnerability to cavitation, or help to repair embolism by compartmentalizing or affecting the contact angle of the convex air-water interface within intervessel pits.
\end{abstract}

Keywords: angiosperms, ecology, embolism, perforation plates, phylogeny, pit borders, vestures, xylem transport.

\section{Introduction}

Vestured pits were first described by Bailey (1933), who discovered under the light microscope that vestures are minute outgrowths from the secondary cell wall. With the advent of the electron microscope, the micromorphology and distribution of vestured pits could be studied in much greater detail during the 1960s and 1970s (Côté and Day 1962; Schmid and Machado 1964; Scurfield et al. 1970; Meylan and Butterfield 1974; Ohtani and Ishida 1976; Van Vliet 1978). Mapping the presence of vestured pits onto recent angiosperm phylogenies based on molecular sequence data has shown that the feature must be under strong genetic control and is diagnostic for all taxa of a number of clades (Jansen et al. 1998, 2000a, 2001; Jansen and Smets 2000; Jørgensen 2001).

Despite the strong systematic significance of vestured pits, functional hypotheses on vestures are largely restricted to untested hypotheses by Zweypfenning (1978) and Carlquist (1982a, 1982b, 2001). Zweypfenning (1978) suggested that vestures prevent rupturing of the deflected pit membranes when pressure drops occur between adjacent vessel elements after air embolism. Carlquist (1982a, 1982b) hypothesized that cavitations might be less frequent because of the presence of vestures or other kinds of wall relief, such as helical thickenings and grooves, since these structures increase the surface area of vessel walls. This was thought to result in an increased bonding of water molecules to the cell-wall surface and to permit the water column to withstand higher tensions without breaking. Another hypothesis is that vestures would trap small

${ }^{1}$ E-mail steven.jansen@bio.kuleuven.ac.be.

Manuscript received January 2002; revised manuscript received January 2003. air bubbles and help to dissolve the trapped gas volume so that normal water transport is restored (Carlquist 1982b).

The major findings in the field of xylem structure in relation to its function in long-distance water transport have been known for a long time and are summarized by Zimmermann (1983). Since then our functional understanding of xylem has changed slightly. We have gained, for instance, new insight into the phenomenon of cavitation (Hacke and Sperry 2001). Cavitation and the subsequent formation of air bubbles in embolized vessels substantially reduce the hydraulic conductivity of xylem (Milburn 1993). As suggested by Zimmermann (1983), there is substantial evidence that cavitation occurs by the "air-seeding" mechanism, which most likely operates at the pit membranes between cavitated and functional conduits (Crombie et al. 1985; Jarbeau et al. 1995; Sperry et al. 1996). The xylem appears to be more active and dynamic in repairing its water conductivity than previously expected. Embolized conduits have been suggested to refill during nightly or seasonal root pressure (Sperry et al. 1994; Ewers et al. 1997; Fisher et al. 1997; Cochard et al. 2001). It is also possible that embolism repair may take place while water in neighboring conduits remains under tension (Salleo et al. 1996; McCully et al. 1998; Zwieniecki and Holbrook 1998; Pate and Canny 1999; Tyree et al. 1999; Melcher et al. 2001). However, it is not clear yet under which conditions embolism can be reversed. A mechanism that allows the local compartmentalization of positive pressures within a single vessel has been hypothesized (Holbrook and Zwieniecki 1999) because positive pressures are required to force the gas into the surrounding liquid phase (Pickard 1981; Yang and Tyree 1992). A more detailed scenario outlined the importance of the geometry of intervessel pits and the nonzero contact angle between the water and the vessel walls of the pit chamber (Zwieniecki and Holbrook 
2000). Although these hypotheses remain speculative, they may throw new light on the functional significance of vestured pits in relation to embolism repair.

If vestured pits are of selective value, as they seem to be, they clearly need more attention with respect to the complex mechanisms of xylem conductivity. On the basis of ecological trends and a strong correlation between vestured pits and type of vessel perforation plate, this article focuses on new functionally adaptive interpretations of vestured pits.

\section{Material and Methods}

For the distribution of vestured pits, we follow our recent review (Jansen et al. 2001) in addition to some new observations (Jørgensen 2001; S. Jansen, unpublished results). Data on vessel perforation types have been collected from the literature, chiefly from Metcalfe and Chalk (1983) and Carlquist (2001).

Ecological trends for vestured pits are analyzed by calculating percentages of species possessing vestured and nonvestured pits in different regions of the world. Difficulties in analyzing floristic accounts of specific vegetation types or regional floras are caused by inaccurate literature data, misidentified taxa, changed names, and anatomically unknown species. Also, the percentages of species with vestured or nonvestured pits in a particular geographic or ecological area may conceivably be entirely explained by the fact that certain families have had much higher rates of speciation than other families in specific regions. Therefore, the analyses of regional wood anatomical surveys are based on as many woody species as possible but underrecord shrubs and lianas. The ecological categories distinguished in the flora from Europe (Baas and Schweingruber 1987), Southern California (Carlquist and Hoekman 1985), and the Middle East (Baas et al. 1983) are followed. Statistics for vestured pits in the world flora are based on data on more than 5500 species in the OPCN $\left(\mathrm{Ox}^{-}\right.$ ford, Princes Risborough, Centre Technique Forestier Tropical, North Carolina State University) database maintained at North Carolina State University (Wheeler et al. 1986; Baas and Wheeler 2000). The distribution of wood anatomical characters is plotted on the tree of Soltis et al. (2000) using MacClade 4.0 (Maddison and Maddison 2000).

\section{Results and Discussion}

\section{The Homoplasious Nature of Vestured Pits}

The systematic distribution of vestured pits plays a central role in considering functional aspects. Even without knowledge of the genetic basis of the character in question, we can infer transformations of nonvestured and vestured vessel pits by comparing their distribution with independent phylogenetic hypotheses. For a preliminary list of angiosperm families with vestured pits, we refer to Jansen et al. (2001). The distribution is plotted on the molecular tree of Soltis et al. (2000) (fig. 1).

Vestured pits show a remarkable constancy in most clades in which they occur. According to recent phylogenetic insights in flowering plants (APG 1998; Savolainen et al. 2000a, 2000 b; Soltis et al. 2000), vestured pits should be considered as one of the most valuable wood anatomical characters with strong phylogenetic signals (Baas et al. 2000; Jansen et al. 2001). Not only are vestured pits constantly present in the large natural orders Myrtales and Gentianales, but the feature also appears to characterize several clades within the Brassicales, Caryophyllales, and Malvales as well as many family pairs and families in other orders. The largest family with vestured pits is Leguminosae, although the feature is lacking in the most basal taxa (Herendeen 2000). In a few instances, such as Bridelieae (Phyllanthaceae) and Polygaleae (Polygalaceae), vestured pits are characteristic only at the tribal level as far as we know.

However, there are reports suggesting that the character is much more variable in its distribution. For example, in the genus Spiraea (Rosaceae), vestured pits are observed in five out of 10 species studied, whereas they are lacking in the rest of the family (Zhang and Baas 1992). A similar variation at low taxonomic levels is suggested in Oleaceae (Baas et al. 1988) and Boraginaceae (Miller 1977). However, it should be emphasized that detailed SEM observations are required since the feature may easily be overlooked under the light microscope. Moreover, numerous families have seen some recent changes in their phylogenetic position, intrafamily classification, and generic composition, which play a central role in analyzing the evolution of character states within a clade.

Another difficulty in analyzing the distribution of the character is that there may be a thin line between presence and absence of the structure. This problem is mainly encountered when vestures are poorly developed structures as, for instance, in Elaeagnaceae (Jansen et al. 2000b) or when vestigial vestures are restricted to particular tracheary elements, especially small vessel elements and tracheids or even fibers. Although vestures are generally consistent in their presence throughout intervessel pits of a certain specimen (Bailey 1933), they may be almost or entirely absent in intervessel pits of at least some taxa but common in bordered pits of tracheids or fiber tracheids. Hence, one should be careful not to interpret the combined occurrence of vestured and nonvestured pits in a wood sample as being completely nonvestured (Jansen et al. 2001). Other problems might be misinterpretation of artifacts or pseudovestures (Gale 1982) and even misidentification of the material studied. Pseudovestures do not form an integral part of the cell wall and are generally more randomly distributed than genuine vestures.

Until we have more data on occurrence and developmental constraints as well as on the exact phylogenetic position of several taxa, we tentatively suggest that there are at least five origins of vestured pits among the angiosperms, namely in Proteales, Caryophyllales, eurosids I, eurosids II, and euasterids I (see fig. 1). The feature is likely to reveal few or no losses in clades such as Myrtales and Gentianales and the nonbasal Leguminosae, but reversible losses are expected in clades where both vestured and nonvestured pits are found (e.g., Caryophyllales, Malvales, Solanales, Oleaceae, Rosaceae).

\section{A Strong Correlation between Vestured Pits and Type of Vessel Perforation Plate}

Although Butterfield and Meylan (1974) have already mentioned that it is uncommon to find the combination of vestures and scalariform perforation plates within a single wood sample, it should be emphasized that vestures occur virtually ex- 


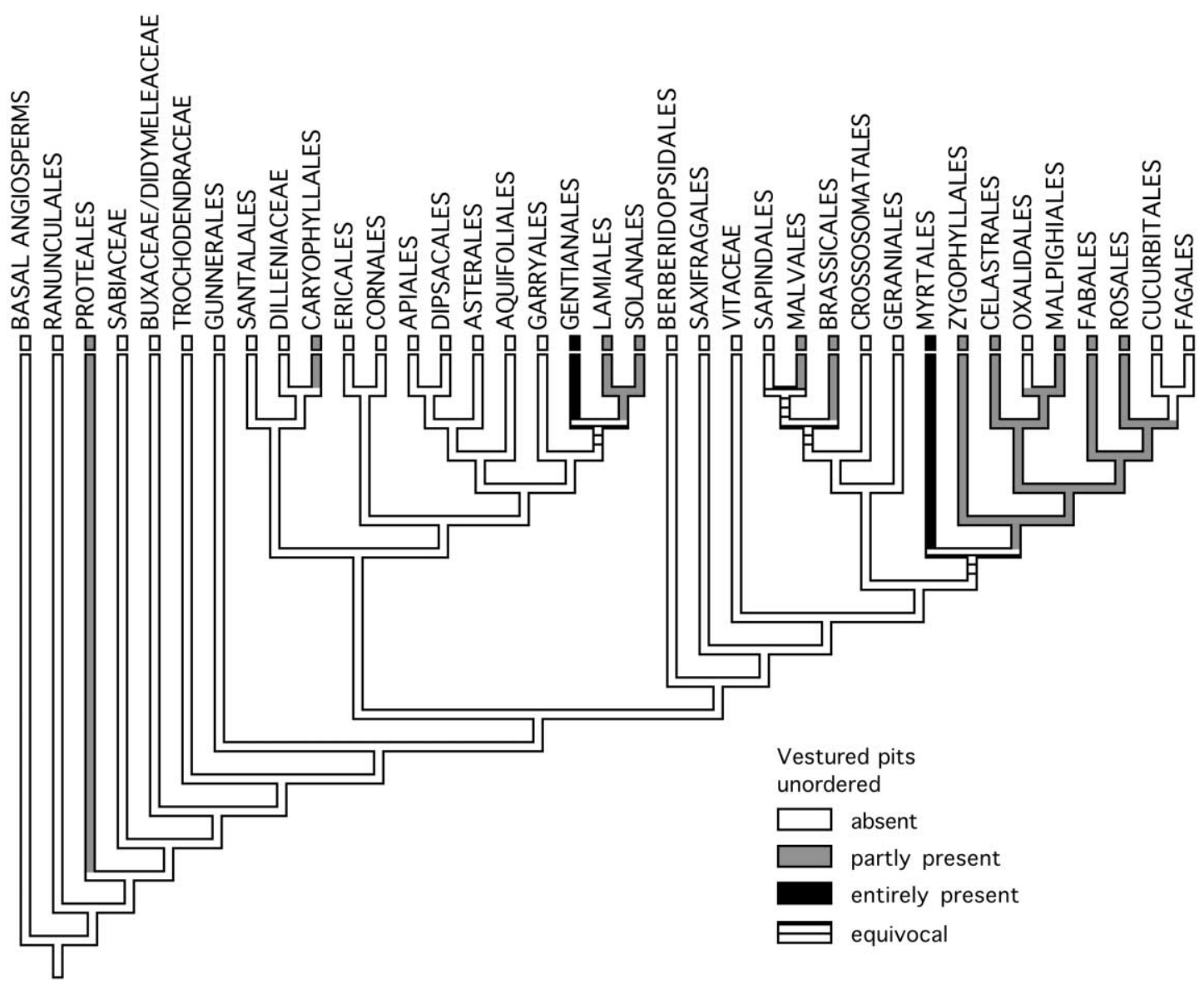

Fig. 1 Distribution of vestured pits plotted on the tree of Soltis et al. (2000); character type unordered

clusively in clades that are characterized by predominantly or exclusively simple perforation plates. The distribution of vestured pits and type of vessel perforation plates is plotted in figure 2 . The main orders with simple vessel perforation plates and vestured pits include Caryophyllales, Gentianales, Lamiales, Solanales, Brassicales, Malvales, Myrtales, Zygophyllales, Fabales, and Rosales. Scalariform perforation plates are rarely or partly present in the Proteales, Brassicales, Malpighiales, and Celastrales, but the combination of this type of vessel perforation plate and vestured pits occurs in hardly any of these taxa. Scalariform vessel perforations are, for instance, frequently present in Phyllanthaceae or the subfamily Phyllanthoideae of Euphorbiaceae, but vessel perforation plates are entirely simple in the single tribe with vestured pits, namely Bridelieae (Mennega 1987). However, by no means do all taxa with simple vessel perforations have vestured pits since, as far as we know, vestures do not occur within the Cucurbitales, Geraniales, and Sapindales.

Few counterexamples can be found. Although Heimsch (1942) describes simple vessel perforation plates for all species of Dichapetalaceae studied, two species of Tapura possess, in addition, scalariform perforation plates as well as vestured pits. Other representatives that show vestures and scalariform perforation plates occur, for instance, in Myrtales. While the majority of this order shows wood with exclusively simple vessel perforation plates, the combination of simple and occasional scalariform vessel perforations is reported in some genera. Within the Myrtaceae, exclusively scalariform perforation plates are reported in Luma, Myrteola, Neomyrtus, and Ugni; they are possibly retained because a selective pressure to eliminate them in cool mesic habitats is lacking (Schmid and Baas 1984). These four genera all have vestured pits, and Neomyrtus pedunculata even has vestured scalariform perforation plates (Butterfield and Meylan 1974, 1980; Meylan and Butterfield 1978). It is clear, however, that sporadic counterexamples do not contradict the strong correlation between vestures and simple perforation plates.

It is not a simple matter to establish a valid correlation between vestured pits and other anatomical characters. There is a positive correlation between vestured pits and alternate vessel pitting, but this seems to be in line with the lack of vestured pits in woods with scalariform perforation plates. Apparently, there is no correlation between the size of vessel pits and vestures, but there might be a mutually exclusive relationship between vestures and tyloses. From the 61 families listed to show tyloses in vessel elements (Metcalfe and Chalk 1983), only seven families have vestured vessel pits in the majority of their representatives. This may be a slight indication that formation of tyloses is prevented in taxa with vestured pits. Tyloses are usually not observed in association with ves- 


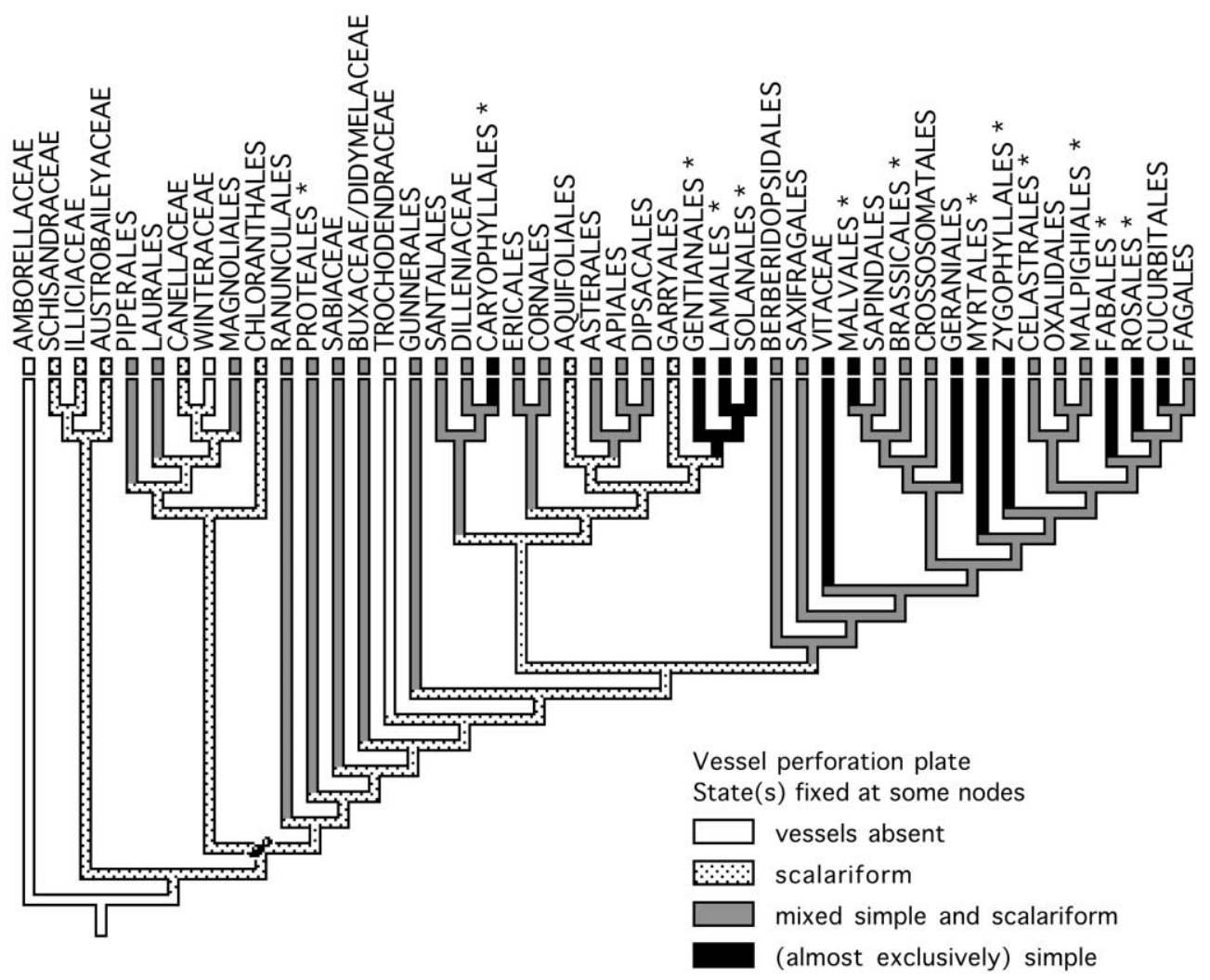

Fig. 2 Types of vessel perforation plate plotted on the tree of Soltis et al. (2000); vestured pits are present in orders indicated by an asterisk; character type irreversible with scalariform perforations fixed at basal node indicated by paintbrush.

tured pits (Foster 1967; Scurfield and Silva 1970; Meylan and Butterfield 1974), but there are certainly exceptions (e.g., Robinia, Fabaceae). In several taxa, pits between a vessel and a ray parenchyma cell can be vestured, partially vestured, or nonvestured on the vessel side, depending on the size and shape of the vessel-ray pits. Tyloses are, for instance, a common feature in Fuchsia excorticata (Onagraceae), in which intervessel pits are always vestured, but the vessel-ray pitting is more rounded and frequently devoid of vestures (Butterfield and Meylan 1973). Moreover, Foster (1967) suggested that the vestures and pit membranes are broken down by enzymes secreted from the ray cell protoplast before tylosis extension takes place.

\section{Ecological Trends in the Distribution of Vestured Pits}

In table 1, a comparison of percentages of woody species with vestured pits from different regions, we find that of the 550 woody species within the European flora studied by Baas and Schweingruber (1987), 115 species ( \pm 3 ; i.e., 23\%) are known to have vestured pits. The ecological spectrum of these species is as follows: $8 \%$ occur in relatively mesic sites, $65 \%$ in dry areas, and $27 \%$ in intermediate (normal) localities. For the 390 species with nonvestured pits, these percentages are $22 \%, 45 \%$, and $33 \%$, respectively. Also, if one considers the latitudinal European zonation of boreal, temperate, and Mediterranean, there is a clear trend: of the 33 boreal species, none have vestures, and $20 \%$ of the 138 temperate species show vestures, while the character is present in $27 \%$ of the 301 Mediterranean woody shrubs and trees. Hence, species with vestured pits appear to show a more xeric preference than species that lack vestures (table 1 ).

Similar results are found for the distribution of species with vestured pits in Southern California (Carlquist and Hoekman 1985), although the total species numbers in the ecological categories distinguished are low. For the 35 species with vestured pits, the percentages are as follows: chapparal, $12.2 \%$ $(n=41)$; coastal sage, $12.1 \%(n=33)$; desert scrubs, $12 \%$ $(n=50)$; desert wash, $23.5 \%(n=17)$; and halophytes, $25 \%$ $(n=4)$. Furthermore, vestured pits do not occur in the species that belong to the ecological categories riparian, moist, alpine, succulent, parasite, and woodland. Six species of Onagraceae, which all show vestured pits, were not classified in any ecological category (Carlquist and Hoekman 1985).

In the woody flora of the Middle East studied by Baas et al. (1983), 29.6\% of the species have vestured pits, but the ecological picture in this region is less clear. The percentages of species with vestures are as follows: arid (desert) species, $31.5 \%(n=76)$; Mediterranean elements, $29 \%(n=41)$; hydrophyllic species, $27 \%(n=11)$; and synanthropic species, $14 \%(n=7)$. These percentages are, however, based on very low total species numbers and are thus fairly unreliable.

There is a discrepancy between the $23 \%$ found for Europe according to Baas and Schweingruber (1987) and the $12.6 \%$ for European and East Asian woods following the OPCN data- 
Table 1

Percentages of Woody Species with Vestured Pits from Different Regions

\begin{tabular}{lccl}
\hline Region & $\begin{array}{c}\text { Species } \\
\text { percentages }\end{array}$ & $\begin{array}{c}\text { Total number } \\
\text { of species }\end{array}$ & \multicolumn{1}{c}{ Reference } \\
\hline Europe and East Asia & 12.6 & 563 & OPCN database \\
Europe & 23 & 550 & Baas and Schweingruber 1987 \\
Middle East & 29.6 & 135 & Baas et al. 1983 \\
North America & 11.8 & 314 & OPCN database \\
Southern California & 17 & 207 & Carlquist and Hoekman 1985 \\
Tropical America & 31.9 & 1965 & OPCN database \\
Brazil & 37.6 & 199 & Mainieri and Chimelo 1989 \\
Amazonia & 38.9 & 1302 & Détienne and Jacquet 1983 \\
Atlantic Rain Forest in Rio & & & \\
$\quad$ de Janeiro state (Brazil) & 38.6 & 31 & Barros and Callado 1997 \\
South America & 45.7 & 848 & Dechamps 1979, 1980, 1985 \\
Temperate South America & 29 & 269 & OPCN database \\
Africa & 34.2 & 1004 & OPCN database \\
Sahara and Sahel & 56.5 & 168 & Neumann et al. 2001 \\
East Sahara & 59 & 27 & Neumann 1989 \\
Saudi Arabia & 50 & 78 & Jagiella and Kürschner 1987 \\
South Africa & 24.5 & 102 & OPCN database \\
Swaziland & 36.5 & 93 & Prior and Gasson 1990 \\
Southeast Asia & 29.5 & 869 & OPCN database \\
India & 29.9 & 605 & OPCN database \\
Java & 26 & 887 & Janssonius 1906-1936 \\
Polynesia & 41 & Détienne and Jacquet 1999 \\
Australia and New Zealand & 33.9 & OPCN database \\
New Zealand & 28.5 & Meylan and Butterfield 1978 \\
\hline
\end{tabular}

Note. Data from the OPCN (Oxford, Princes Risborough, Centre Technique Forestier Tropical, North Carolina State University) database are from E. A. Wheeler (personal communication).

base. This may be explained by the high proportion of Mediterranean shrubs and subshrubs such as Cistus and numerous Leguminosae in the former analysis. Moreover, subshrubs are probably underrepresented in the OPCN database, and some taxa in which vestured pits have only recently been described may still be reported as nonvestured pits in the OPCN database.

The best statistic for vestured pits in the world flora is $29 \%$ from the OPCN database. Inferences for tropical percentages are very close to world statistics because there are ca. 4000 tropical species and only ca. 1000 temperate species in the OPCN database.

The suggestion that vestured pits are more widespread in warmer and xeric regions is further corroborated by percentages for different regions in America and Africa. While the character occurs in $11.8 \%$ of North American species, fractions above $30 \%$ are found for tropical South America. Very high percentages $(45.7 \%)$ are obtained for the woody species from South America studied by Dechamps (1979, 1980, 1985). The highest frequency of vestured pits is in species from the Sahara and the Sahel (Neumann 1989; Neumann et al. 2001). Within the species from Swaziland studied by Prior and Gasson (1990), the percentages of vestured pitting in the cooler Afromontane species and warmer Bushveld species are $25.5 \%$ $(n=43)$ and $46 \%(n=50)$, respectively.

Percentages of taxa with vestured pits in Southeast Asia, India, Java, Australia, and New Zealand are in agreement with these for the world. One may expect that the proportion in tropical lowland forests will be higher because of the high species diversity of Dipterocarpaceae, Leguminosae, Rubiaceae, and Melastomataceae, which are all characterized by vestured pits.

In general, the overall habitat preferences of plants with vestures are the tropics and subtropics rather than the cool temperate to arctic or alpine floras, as has been suggested previously (Schmid and Machado 1964; Zweypfenning 1978). We therefore suggest that vestured pits have a positive adaptive significance for water transport in woody plants that develop high negative pressures in their xylem. This may especially occur in xeric environments (e.g., deserts) or warm climates with high transpiration rates but mesic conditions (e.g., tropical rainforests).

However, plants in the same area may develop various wood anatomical patterns and exploit the environment in different ways to deal with hydraulic demands (Carlquist 2001). Therefore, ecological trends for vestured pits are not always significant, and correlations may become complex. It is also possible that vestured pits may have little or no negative selective significance when a shift occurs from environments with high to low transpiration rates or from high to low negative xylem pressures.

\section{New Functionally Adaptive Interpretations of Vestured Pits}

The correlation between vestured pits and simple perforation plates seems to indicate that the evolutionary shift from scalariform to simple perforations is a prerequisite for the de- 
velopment of vestured pits, and this may have a functional explanation. Moreover, there are significant ecological tendencies for types of vessel perforation plate and vestured pits. Scalariform vessel perforation plates occur most frequently in temperate to boreal and alpine regions, where this type of vessel perforation could have a function in reducing freezinginduced embolism, but more experimental evidence is needed (Carlquist 1975, 2001; Baas 1976, 1986; Zimmermann 1983). Vestured pits are rarely found in these regions but tend to be much more common in xeric and warmer floras with high transpiration rates. These remarkable correlations have inspired us to suggest that vestures represent a mechanism promoting safety of water transport and enabling plants to compensate for decreases in safety by reducing the effects of drought-induced embolism.

It is generally believed that vessel elements with simple perforation plates are more efficient conductors of water (because there is less friction) but are less safe than vessels with scalariform perforations because of higher risks of cavitation and embolism (Carlquist 1975, 2001). Indeed, many wood anatomical data indicate that there is a phylogenetic reduction of bars in scalariform perforation plates in environments where a higher flow rate is likely. This can be illustrated, for instance, in tropical lowland species, in xeric plants, and in climbers, which are all recorded to show at least temporarily high sap flow velocities (Baas 1976). The low relative conductivity of birch wood (Betulaceae) measured using water and dry air was found to be $34 \%$ and $38 \%$, respectively, of that calculated from microscopic measurements assuming the vessels to be unobstructed capillaries (Petty 1978). This was interpreted as a result of the resistance to viscous flow at scalariform perforation plates and the presence of some vessels that terminate in the wood sample. Contrary to this, scalariform perforation plates are thought to form only slight obstructions to water flow in Liquidambar (Hamamelidaceae) and Liriodendron (Magnoliaceae) (Schulte et al. 1989). These authors suggested that their advantage from an evolutionary point of view would be much more in trapping gas bubbles and thus preventing the blockage of entire vessels. The extra resistance to flow along a vessel provided by perforation plates was calculated to account for $0.6 \%-18 \%$ and is much lower than the resistance of the vessel walls (Ellerby and Ennos 1998). The scalariform perforation plates in Liquidambar styraciflua were calculated to account for $21 \%-23 \%$ of the total resistance to flow encountered along a vessel (Schulte 1999). Simple plates are concluded to provide less resistance than scalariform perforation plates, but resistance values of perforation types may overlap because simple perforation plates are generally more closely arranged in shorter vessel elements than scalariform perforations (Ellerby and Ennos 1998). Further experimental studies are required to investigate the effect of vessel perforation plates on conductive efficiency and flow resistance.

Besides vessel perforation plates, functional adaptations in the micromorphology of pits may contribute considerably to the hydraulic mechanism of tracheary elements. Ideally, a safe vessel element will benefit from minute, distinctly bordered vessel pits and nonporous pit membranes, but a balance will generally be achieved between safety and efficiency of water transport. The hydraulic efficiency of intervessel pits could probably be increased by a large surface area of pit chambers and pit membranes with large pores (Tyree et al. 1994). With respect to a hypothetical scenario of embolism repair, Holbrook and Zwieniecki (1999) proposed that the bordered vessel pits play an essential role in hydraulic compartmentalization and minimalization of the gas volume in pit borders, resulting in hydraulic reconnection to adjacent water-filled vessels. Because of the flared opening of the pit border and the chemical composition of the vessel wall surfaces, intervessel pits allow, at the same time, the creation of a positive pressure in the refilling vessel and a negative pressure in adjacent vessels under tension (Zwieniecki and Holbrook 2000). Accordingly, bordered pits are thought to function as a hydraulic valve, since a convex air-water surface that is formed in the pit border creates a surface tension force that opposes the pressure that forces the air in the refilling vessel into solution (fig. 3). Support for this view comes from measurements of the contact angle and pit-chamber geometry, which allow the calculation of the maximum pressure that can be contained within a refilling conduit, and data from Zwieniecki et al. (2001). Nevertheless, there is still much uncertainty as to the extent to which embolism repair occurs as well as the underlying mechanism. A major problem with this refilling hypothesis is that hydraulic contact should be at all pits simultaneously or else the refilling vessel element would recavitate when hydraulic contact is reestablished at one pit only.

Because of a lack of experimental data on plants with vestured pits, it is too early to conclude that vestures have a positive influence on isolation of the hydraulic conduit. Nevertheless, the following observations support the possible role of vestures in mechanisms of embolism repair. (1) If vestures are present, they are nearly always associated with bordered pits of water-conducting elements (vessels, tracheids, and fiber tracheids), but they are never associated with simple pits of

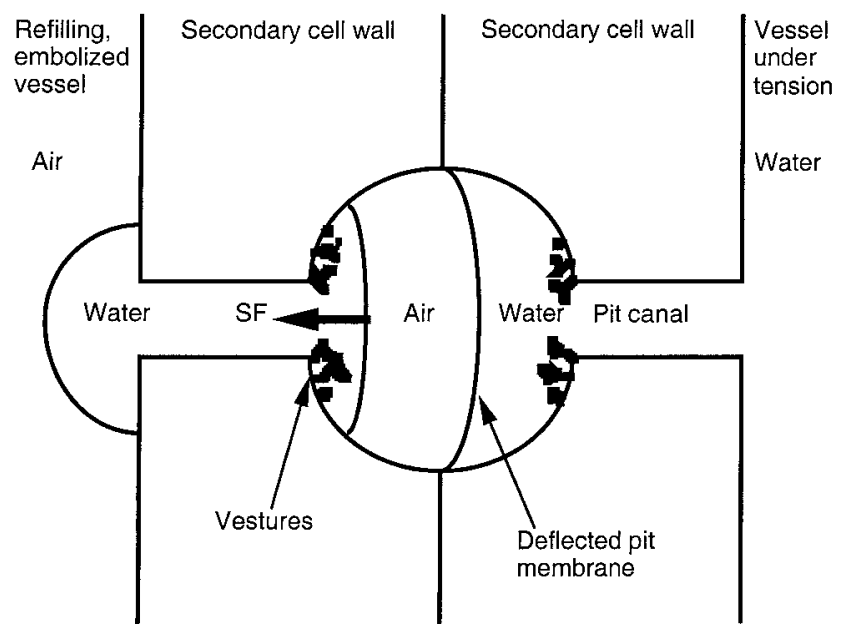

Fig. 3 Diagram of a vestured vessel pit isolating a refilling, embolized vessel lumen (left) and a functional vessel under tension (right). The pressure drop deflects the pit membrane to the right. Water has entered the bordered pit canal at left; the presence of vestures near the outer pit aperture may affect the air-water interface by increasing the surface force (arrow SF), which prevents further expansion into the pit border and opposes the positive pressure needed to refill the embolized vessel. Based on Zwieniecki and Holbrook (2000). 
parenchyma cells and simple to very minutely bordered pits of fibers (Meylan and Butterfield 1974; Ohtani and Ishida 1976; Jansen et al. 1998). (2) Vestures are formed mainly of lignin, which is probably even more concentrated and condensed than the lignin elsewhere in the cell wall, but cellulose is lacking (Côté and Day 1962; Scurfield and Silva 1970; Mori et al. 1983). Like other parts of the vessel wall, lignin makes the vestures "waterproof" or hydrophobic (McCann 1997), which probably guarantees a nonzero contact angle and allows the hydraulic isolation needed for embolism repair to occur (Holbrook and Zwieniecki 1999). The highly hydrophobic nature of vestures also pleads against one of Carlquist's hypotheses that there is better adherence of the water column to the vessel wall in the presence of vestures or warts. (3) It is evident that the presence of vestures near the outer (frequently also inner) pit aperture changes the geometry of the pit chamber. This will undoubtedly have an effect on the contact angle of the water-air interface within the pit chamber, primarily by affecting $G$ (ratio of perimeter to area, which scales as $2 / r$ ). Compared with wood with nonvestured pits, this may allow higher differences in pressure between water in the lumen and gas that is stabilized by the convex air-water interface in the vestured pit chamber. Correspondingly, it will take more pressure to push the water into the pit chambers to fill them. This could be a more efficient way to refill the embolized vessel lumen, but it could also mean that the pressure has to build up sufficiently to eventually fill up the pit chamber (fig. 3).

Clearly, experimental work addressing functional properties of vestures is required to investigate how the presence of vestures may have an impact on embolism repair. There is still much to be learned about the physical and biomechanical role of intervessel pits. Another question that should be addressed is whether vestures provide any mechanical support that prevents the pit membrane from rupturing (Zweypfenning 1978). Further work is also needed to determine the effect of vestures on the hydraulic resistance through pits. New techniques like the vessel-casting method and the single-vessel technique could be useful in this regard (André 1993, 2001; Zwieniecki et al. 2001). It is clear that fruitful studies on functional hypotheses of vestured pits require a multidisciplinary approach covering xylem physiology, systematic wood anatomy, plant phylogeny, and ecology.

\section{Acknowledgments}

We thank Missy Holbrook for valuable comments on an earlier draft of this article and Elisabeth Wheeler for the percentages of vestured pits based on the OPCN database. Research at the Laboratory of Plant Systematics is supported by grants from the Research Council of the Katholieke Universiteit Leuven (OT/01/ 25) and the Fund for Scientific Research-Flanders (Belgium) (G.104.01). Steven Jansen is a postdoctoral fellow of the Fund for Scientific Research-Flanders (Belgium) (F.W.O.Vlaanderen) and is currently working at the Jodrell Laboratory, Royal Botanic Gardens, Kew.

\section{Literature Cited}

André J-P 1993 Micromoulage des espaces vides intra et intercellulaire dans les tissus végétaux. C R Acad Sci Paris 316:1336-1341.

2001 Heterogeneous, branched, zigzag and circular vessels: unexpected but frequent forms of tracheary element files: description-localization-formation. Pages 387-395 in R Savidge, J Barnett, R Napier, eds. Cell and molecular biology of wood formation. BIOS Scientific, Oxford.

APG (Angiosperm Phylogeny Group) 1998 An ordinal classification for the families of flowering plants. Ann Mo Bot Gard 85:531-553.

Baas P 1976 Some functional and adaptive aspects of vessel member morphology. Pages 157-181 in P Baas, AJ Bolton, DM Catling, eds. Wood structure in biological and technological research. Leiden Bot Ser 3. Leiden University Press, Leiden.

1986 Ecological patterns in xylem anatomy. Pages 327-353 in J Givnish, ed. On the economy of plant form and function. Cambridge University Press, Cambridge.

Baas P, PM Esser, MET van der Westen, M Zandee 1988 Wood anatomy of the Oleaceae. Int Assoc Wood Anat Bull, NS, 9:103-182.

Baas P, FH Schweingruber 1987 Ecological trends in the wood anatomy of trees, shrubs and climbers from Europe. Int Assoc Wood Anat Bull, NS, 8:245-274.

Baas P, E Werker, A Fahn 1983 Some ecological trends in vessel characters. Int Assoc Wood Anat Bull, NS, 4:141-159.

Baas P, EA Wheeler 2000 Wood structure of Southeast Asian timbers: the PROSEA woods reviewed. Pages 1-9 in YS Kim, ed. New horizons in wood anatomy. Chonnam National University Press, Kwangju.

Baas P, EA Wheeler, MW Chase 2000 Dicotyledonous wood anatomy and the APG system of angiosperm classification. Bot J Linn Soc 134:3-17.

Bailey IW 1933 The cambium and its derivative tissues. VIII. Struc- ture, distribution and diagnostic significance of vestured pits in dicotyledons. J Arnold Arbor Harv Univ 14:259-273.

Barros CF, CH Callado 1997 Timbers of the Atlantic rain forest. Vol 1. Wood anatomy of species from remnant forests in Rio de Janeiro State-Brazil. Jardim Botânico do Rio de Janeiro, Rio de Janeiro.

Butterfield BG, BA Meylan 1973 Scanning electron micrographs of New Zealand woods. 3. Fuchsia excorticata (J.R. et G. Forst.) Linn.f. N Z J Bot 11:411-420.

1974 Vestured scalariform perforation plate openings in Neomyrtus pedunculata. Aust J Bot 22:425-427.

1980 Three-dimensional structure of wood: an ultrastructural approach. 2d ed. Chapman \& Hall, London.

Carlquist S 1975 Ecological strategies of xylem evolution. University of California Press, Berkeley.

1982a Wood anatomy of Illicium (Illiciaceae): phylogenetic, ecological, and functional interpretations. Am J Bot 69:1587-1598.

$-1982 b$ Wood anatomy of Onagraceae: further species, root anatomy, significance of vestured pits and allied structures in dicotyledons. Ann Mo Bot Gard 69:755-769.

2001 Comparative wood anatomy: systematic, ecological, and evolutionary aspects of dicotyledon wood. $2 \mathrm{~d}$ ed., completely revised. Springer, Berlin.

Carlquist S, DA Hoekman 1985 Ecological wood anatomy of the woody southern Californian flora. Int Assoc Wood Anat Bull, NS, 6:319-347.

Cochard H, D Lemoine, T Ameglio, A Granier 2001 Mechanisms of xylem recovery from winter embolism in Fagus sylvatica. Tree Physiol 21:27-33.

Côté WA, AC Day 1962 Vestured pits: fine structure and apparent relationship with warts. Tech Assoc Pulp Pap Ind 45:906-910.

Crombie DS, MS Hipkins, JA Milburn 1985 Gas penetration of pit 
membranes in the xylem of Rhododendron and other species. Planta 163:27-33.

Dechamps R 1979 Etude anatomique de bois d'Amerique du Sud. Vol 1. Acanthaceae à Lecythidaceae. Ann Mus R Afr Cent Tervuren, Sér IN-8, Sci Econ, no 10. 332 pp.

1980 Etude anatomique de bois d'Amerique du Sud. Vol 2. Leguminosae. Ann Mus R Afr Cent Tervuren, Sér IN-8, Sci Econ, no 11.229 pp.

1985 Etude anatomique de bois d'Amerique du Sud. Vol 3. Linaceae à Quinaceae. Ann Mus R Afr Cent Tervuren, Sér IN-8, Sci Econ, no. 14. 471 pp.

Détienne P, P Jacquet 1983 Atlas d'identification des bois de l'Amazonie et des régions voisines. Centre Technique Forestier Tropical, Nogentsur-Marne. $640 \mathrm{pp}$.

1999 Manuel d'identification des bois de Polynésie. Montpellier, France, Cirad, Cnrs, Mnhn. 84 pp.

Ellerby DJ, AR Ennos 1998 Resistances to fluid flow of model xylem vessels with simple and scalariform perforation plates. J Exp Bot 49:979-985.

Ewers FW, H Cochard, MT Tyree 1997 A survey of root pressures in vines of a tropical lowland forest. Oecologia 110:191-196.

Fisher J, G Angeles, FW Ewers, J Lopez-Portillo 1997 Survey of root pressure in tropical vines and woody species. Int J Plant Sci 158: 44-50.

Foster RC 1967 Fine structure of tyloses in three species of the Myrtaceae. Aust J Bot 15:25-34.

Gale R 1982 Some pitfalls in wood identification, with reference to Nothofagus. Int Assoc Wood Anat Bull 3:179-184.

Hacke UG, SJ Sperry 2001 Functional and ecological xylem anatomy. Perspect Plant Ecol Evol Syst 4:97-115.

Heimsch C 1942 Comparative anatomy of the secondary xylem in the "Gruinales" and "Terebinthales" of Wettstein with reference to taxonomic grouping. Lilloa 8:83-198.

Herendeen PS 2000 Structural evolution in the Caesalpinioideae (Leguminosae). Pages 45-64 in PS Herendeen, A Bruneau, eds. Advances in legume systematics 9. Royal Botanic Gardens, Kew.

Holbrook NM, MA Zwieniecki 1999 Embolism repair and xylem tension: do we need a miracle? Plant Physiol 120:7-10.

Jagiella C, H Kürschner 1987 Atlas der Hölzer Saudi Arabiens. Beihefte zum Tübinger Atlas des Vorderen Orients Reihe A (Naturwissenschaften) Nr. 20. Dr. Ludwig Reichert, Wiesbaden. 176 pp.

Jansen S, P Baas, E Smets 2000a Vestured pits in the Malvales s.l.: a character with taxonomic significance hidden in the secondary $\mathrm{xy}$ lem. Taxon 49:169-182.

2001 Vestured pits: their occurrence and systematic importance in eudicots. Taxon 50:135-167.

Jansen S, F Piesschaert, E Smets $2000 b$ Wood anatomy of Elaeagnaceae, with comments on vestured pits, helical thickenings, and systematic relationships. Am J Bot 87:20-28.

Jansen S, E Smets 2000 Morphology, distribution, and systematic importance of vestures in the Gentianales. Pages 277-296 in B Nordenstam, G El-Ghazaly, M Kassas, eds. Plant systematics for the 21st century. Wenner-Gren International Series, vol 77. Portland, London.

Jansen S, E Smets, P Baas 1998 Vestures in woody plants: a review. Int Assoc Wood Anat J 19:347-382.

Janssonius HH 1906-1936 Mikrographie des Holzes der auf Java vorkommenden Baumarten. 1-6. EJ Brill, Leiden.

Jarbeau JA, FW Ewers, SD Davis 1995 The mechanism of water stress-induced embolism in two species of chapparal shrubs. Plant Cell Environ 18:189-196.

Jørgensen LB 2001 Distribution of vestured pits in glucosinolate plants. Page 52 in T Stuessy, V Mater, E Hörandl, R Buchner, eds. Towards a renaissance of morphology in plant systematics. International Symposium Deep Morphology, October 18-21. Institute of Botany, University of Vienna.
Madison WP, DR Madison 2000 MacClade: interactive analysis of phylogeny and character evolution, version 4.0. Sinauer, Sunderland, Mass.

Mainieri C, JP Chimelo 1989 Fichas de características das madeiras Brasileiras. Instituto de Pesquisas Tecnológicas, São Paulo.

McCann MC 1997 Tracheary element formation: building up to a dead end. Trends Plant Sci 2:333-338.

McCully ME, CX Huang, LE Ling 1998 Daily embolism and refilling of xylem vessels in the roots of field-grown maize. New Phytol 138: 327-342.

Melcher PJ, G Goldstein, FC Meinzer, DE Yount, TJ Jones, MN Holbrook, CX Huang 2001 Water relations of coastal and estuarine Rhizophora mangle: the dynamics of embolism formation and repair. Oecologia 126:182-192.

Mennega AMW 1987 Wood anatomy of the Euphorbiaceae, in particular of the subfamily Phyllanthoideae. Bot J Linn Soc 94:111-126.

Metcalfe CR, L Chalk 1983 Anatomy of the dicotyledons. Vol 2. Wood structure and general introduction. $2 \mathrm{~d}$ ed. Clarendon, Oxford.

Meylan BA, BG Butterfield 1974 Occurrence of vestured pits in the vessels and fibres of New Zealand woods. N Z J Bot 12:3-18.

1978 The structure of New Zealand woods. N Z Dep Sci Ind Res Bull 222, Wellington. 250 pp.

Milburn JA 1993 Cavitation: a review: past, present and future. Pages 14-26 in M Borghetti, J Grace, A Raschi, eds. Water transport in plants under climatic stress. Cambridge University Press, Cambridge.

Miller RB 1977 Vestured pits in Boraginaceae. Int Assoc Wood Anat Bull, NS, 3:43-48.

Mori N, M Fujita, H Harada, H Saiki 1983 Chemical composition of vestures and warts examined by selective extraction on ultrathin sections. Bull Kyoto Prefect Univ For 55:299-306.

Neumann K 1989 Zur Vegetationsgeschichte der Ostsahara im Holozän: Holzkohlen aus prähistorischen Fundstellen. Pages 13-181 in $\mathrm{R}$ Kuper, ed. Forschungen zur Umweltgeschichte der Ostsahara. Africa Praehistorica 2. Heinrich-Barth-Institut, Köln.

Neumann K, W Schoch, P Détienne, FH Schweingruber 2001 Woods of the Sahara and the Sahel: an anatomical atlas. Eidg. Forschungsanstalt WSL, Birmensdorf \& Paul Haupt, Bern. 465 pp.

Ohtani J, S Ishida 1976 Study on the pit of wood cells using scanning electron microscopy. 5. Vestured pits in Japanese dicotyledonous woods. Res Bull Coll Exp For Hokkaido Univ 33:407-435.

Pate JS, MJ Canny 1999 Quantification of vessel embolisms by direct observation: a comparison of two methods. New Phytol 141:33-44.

Petty JA 1978 Fluid flow through the vessels of birch wood. J Exp Bot 29:1463-1469.

Pickard WF 1981 The ascent of sap in plants. Prog Biophys Mol Biol 37:181-229.

Prior JAB, PE Gasson 1990 Comparative wood anatomy of Afromontane and Bushveld species from Swaziland, South Africa. Int Assoc Wood Anat Bull, NS, 11:319-336.

Salleo S, MA Lo Gullo, D De Paoli, M Zippo 1996 Xylem recovery from cavitation-induced embolism in young plants of Laurus nobilis: a possible mechanism. New Phytol 132:47-56.

Savolainen V, MW Chase, SB Hoot, CM Morton, DE Soltis, C Bayer, MF Fay, et al 2000a Phylogenetics of flowering plants based on combined analysis of plastid atpB and $r b c \mathrm{~L}$ gene sequences. Syst Biol 49:306-362.

Savolainen V, MF Fay, DC Albach, A Backlund, M van der Bank, KM Cameron, SA Johnson, et al 2000b Phylogeny of the eudicots: a nearly complete familial analysis based on $r b c \mathrm{~L}$ gene sequences. Kew Bull 55:257-309.

Schmid R, P Baas 1984 The occurrence of scalariform perforation plates and helical vessel wall thickenings in wood of Myrtaceae. Int Assoc Wood Anat Bull, NS, 5:197-215.

Schmid R, RD Machado 1964 Zur Entstehung und Feinstruktur skulpturierter Hoftüpfel bei Leguminosen. Planta 60:612-626. 
Schulte PJ 1999 Water flow through a 20-pore perforation plate in vessels of Liquidambar styraciflua. J Exp Bot 50:1179-1187.

Schulte PJ, AC Gibson, PS Nobel 1989 Water flow in vessels with simple or compound perforation plates. Ann Bot 64:171-178.

Scurfield G, SR Silva 1970 The vestured pits of Eucalyptus regnans F.Muell.: a study using scanning electron microscopy. Bot J Linn Soc 63:313-320.

Scurfield G, SR Silva, HD Ingle 1970 Vessel wall structure: an investigation using scanning electron microscopy. Aust J Bot 18: 301-312.

Soltis DE, PS Soltis, MW Chase, ME Mort, DC Albach, M Zanis, V Savolainen, et al 2000 Angiosperm phylogeny inferred from a combined data set of $18 \mathrm{~S}$ rDNA, rbcL, and atpB sequences. Bot J Linn Soc 133:381-461.

Sperry JS, KL Nichols, SEM Sullivan, SE Eastlack 1994 Xylem embolism in ring-porous, diffuse-porous, and coniferous trees of northern Utah and interior Alaska. Ecology 75:1736-1752.

Sperry JS, NZ Saleindra, WT Pockman, H Cochard, P Cruiziat, SD Davis, FW Ewers, MT Tyree 1996 New evidence for large negative xylem pressures and their measurement by the pressure chamber method. Plant Cell Environ 19:427-436.

Tyree MT, SD Davis, H Cochard 1994 Biophysical perspectives of xylem evolution: is there a trade-off of hydraulic efficiency for vulnerability to dysfunction? Int Assoc Wood Anat J 15:335-360.

Tyree MT, S Salleo, A Nardini, MA LoGullo, R Mosca 1999 Refilling of embolized vessels in young stems of laurel: do we need a new paradigm? Plant Physiol 120:11-21.

Van Vliet GJCM 1978 Vestured pits of Combretaceae and allied families. Acta Bot Neerl 27:273-285.

Wheeler EA, RG Pearson, CA Lapasha, W Hatley, T Zack 1986 Computer-aided wood identification. N C Agric Res Serv Bull 474, Raleigh, N.C. 160 pp.

Yang S, MT Tyree 1992 A theoretical model of hydraulic conductivity recovery from embolism with comparison to experimental data on Acer saccharum. Plant Cell Environ 15:633-643.

Zhang S-Y, P Baas 1992 Wood anatomy of trees and shrubs from China. III. Rosaceae. Int Assoc Wood Anat Bull, NS, 13:21-91.

Zimmermann MH 1983 Xylem structure and the ascent of sap. Springer, Berlin. 143 pp.

Zweypfenning RCVJ 1978 A hypothesis on the function of vestured pits. Int Assoc Wood Anat Bull 1:13-15.

Zwieniecki MA, NM Holbrook 1998 Short term changes in xylem water conductivity in white ash, red maple, and Sitka spruce. Plant Cell Environ 21:1173-1180.

2000 Bordered pit structure and vessel wall surface properties: implications for embolism repair. Plant Physiol 123:1015-1020.

Zwieniecki MA, PJ Melcher, NM Holbrook 2001 Hydraulic properties of individual xylem vessels of Fraxinus americana. J Exp Bot 52:257-264. 